\title{
Аналіз частоти та характеру перебігу соматичної патології спортсменів
}

\author{
С. С. Люгайло
}

Національний університет фізичного виховання і спорту України, Київ, Україна

\begin{abstract}
Резюме. Рассмотрено современное состояние проблемы влияния факторов тренировочной и соревновательной деятельности на клиническое течение соматических заболеваний у спортсменов. Исходя из данных анализа показателей диагностированной у спортсменов соматической патологии, определены особенности ее клинического течения на первом-третьем этапах многолетней подготовки. Установлено, что 75, 11 \% соматических заболеваний имеют острое течение, обострение хронических заболеваний в течение цикла годичной подготовки зарегистрировано у 8,98 \% спортсменов. Также проанализирована динамика изменения показателей количества спортсменов с хронической соматической патологией за период с 2011 по 2013 г. Сделано заключение о необходимости разработки программ физической реабилитации спортсменов с соматическими заболеваниями и интеграции их в процесс многолетней подготовки в целях снижения заболеваемости данного контингента.
\end{abstract}

Ключевые слова: заболеваемость, клиническое течение, спортсмены, факторы риска, физическая реабилитация.

\begin{abstract}
Summary. The currect state of the issue of training and competitive activity factor influence upon clinical course of somatic diseases in athletes has been considered. On the basis of indices of detected somatic pathology in athletes the peculiarities of its clinical course at the first-third stages of long-term preparation have been determined. $75,11 \%$ of somatic diseases has been found to be of acute course; exacerbation of chronic diseases within annual preparation cycle has been observed in $8,98 \%$ of athletes. Besides, the dynamics of changes of the number of athletes with chronic somatic pathology from 2011 to 2013 has been analyzed. It has been concluded that the programs of physical rehabilitation of athletes with somatic diseases should be developed and integrated in the process of long-term preparation in order to decrease the incidence of diseases among the given contingent. Key words: incidence of diseases, clinical course, athletes, risk factors, physical rehabilitation.
\end{abstract}

Постановка проблеми. Здоров'я спортсмена $\epsilon$ основою зростання спортивної майстерності i визначає рівень його професійної надійності $[2,4]$. Науковими дослідженнями доведено, що здоров'я динамічно змінюється протягом процесу багаторічної підготовки і, на жаль, не завжди на краще $[1,16,23]$. Провідні вчені констатують, що погіршення показників здоров'я спортсменів відбувається на всіх етапах підготовки і залежить від чинників тренувальної та змагальної діяльності $[9,10,23]$. При цьому маркери явищ дезадаптації проявляються в органах систем, які несуть основне навантаження у процесі тренування у критичні періоди онтогенезу [3, 6, 8, 12, 19]; ця закономірність особливо виражена у дитячоюнацькому спорті [18, 21, 24]. Вищевикладене підтверджує актуальність розробки програм здоров'язберігаючої спрямованості та впровадження їх у процес підготовки спортсменів різних спеціалізацій на всіх його етапах [9] .

Як свідчить аналіз літературних джерел, заходи з охорони здоров'я населення повинні носити безперервний, обгрунтований характер та бути спрямованими на профрілактику, тобто на усунення фракторів ризику виникнення патології, а за відсутності такої можливості - на корекцію негативних зрушень гомеостазу, та нівелювання їхніх наслідків $[2,4]$. При цьому слід пам'ятати, що програми профрілактики та реабілітації можуть надати очікуваних прогнозованих результатів за умов складання їх з урахуванням негативних тенденцій у стані здоров'я групи осіб, для яких вони складаються, і базування на реальних показниках, які можна контролювати протягом тривалого проміжку часу [18].

Особливий інтерес має інфоормація щодо клінічного перебігу діагностованих у спортсменів захворювань [1, 7, 22], оскільки вивчення взаємозв'язку між особливостями виникнення гострої та хронічної патології провідних систем організму спортсменів та фракторами процесу підготовки, до яких належать спортивна спеціалізація, кваліфікація та період (етап) підготовки, дозволяє максимально індивідуалізувати програмами профрілактики захворювань спортсменів та реабілітації після них. Водночас у сучасній 
спортивній науці практично відсутні комплексні дані про особливості клінічного перебігу захворювань у представників різних видів спорту та його змін у процесі багаторічної підготовки. Однаковою мірою це стосується всіх етапів підготовки за перевагою дитячо-юнацького етапу.

У нашому дослідженні зроблено спробу аналізу клінічного перебігу діагностованих у спортсменів Донецької області соматичних захворювань і тенденцій зміни хронічної патології за період з 2011 по 2013 р.

Роботу виконано згідно зі Зведеним планом НДР на 2011-2015 рр. за темою «Вдосконалення організаційних та методичних засад програмування процесу фрізичної реабілітації при дисфункціональних порушеннях у різних системах організму людини» (номер держреєстрації 0111U001737) та відповідно до регіональної цільової Програми розвитку фрізичної культури і спорту в Донецькій області на 2012-2016 рр.

Мета дослідження: виходячи з аналізу даних щодо частоти виникнення соматичної патології, діагностованої у юних спортсменів різних спеціалізацій, та характеру її клінічного перебігу, визначити основні тенденції зміни цих показників залежно від фракторів тренувальної діяльності протягом першого-третього етапів процесу багаторічної підготовки, а також перспективних напрямків для подальшого поглибленого вивчення проблеми впливу фракторів тренувальної та змагальної діяльності на показники здоров'я даного контингенту спортсменів.

Методи та організація дослідження. Аналіз структури соматичних захворювань різних нозологічних груп відповідно до клінічного перебігу було проведено на основі вивчення звітної документації щодо диспансерного спостереження за спортсменами Донецької області за 2013 р. (форма МОЗ України № 52 - «Здоровий», фрорма № 20), та диспансерних звітів лікарів-кураторів видів спорту обласного лікувально-фрізкультурного диспансеру (ОЛФД) м. Донецьк. Проаналізовано дані про стан здоров'я 5437 юних спортсменів віком від 8 до 17 років різних спортивних спеціалізацій та кваліфікацій. Диспансерне спостереження вказаного контингенту спортсменів, які тренуються на першому-третьому етапах багаторічної спортивної підготовки, проводилося згідно зі встановленим алгоритмом, що передбачав медичне обстеження у таких формах: етап початкової підготовки одне поглиблене медичне обстеження (ПМО) у рік, та додаткове медичне обстеження (ДМО) після перенесених травм та захворювань; етап попередньої базової підготовки - два ПМО у рік, поточне медичне спостереження (ПМС) - за проханнями тренерського складу (здійснюється медичним персоналом спортивних споруд, на яких тренуються спортсмени, або лікарями ДЮСШ) та ДМО - після перенесених захворювань або травм; етап спеціалізованої базової підготовки три ПМО у рік, миттєвий контроль у фрормі лікарсько-педагогічні спостережень (ЛПС) - два рази на рік, ДМО - після травм та захворювань, ПМС - не рідше одного разу на місяць.

Кількість методів дослідження, що використовувалися під час обстеження, залежала від фоорми контролю та спортивної кваліфрікації обстежуваних (етапу підготовки). Під час ПМО спортсменів, які тренуються на першому-другому етапах багаторічної підготовки, використовувалися такі методи: клінічні (загальний та спортивний анамнези, огляд, перкусія, пальпація) та параклінічні (антропометрія: довжина та маса тіла, спірометрія, динамометрія, вимірювання загальних обхватних розмірів тулуба та кінцівок); фрункціональні (ЕКГ), огляд лікарів-фрахівців (невролога, отоларинголога, окуліста, стоматолога, дерматолога, гінеколога, психолога); лабораторні (стандартні методи дослідження крові та сечі). До алгоритму обстеження спортсменів, які тренуються на етапі спеціалізованої базової підготовки, було включено також додаткові методи: ультразвукове внутрішніх органів (УЗД), комп'ютерну спірографрію та експрес-діагностику фрункціонального стану і резервних можливостей організму за методикою С. О. Душаніна, В. П. Карленко (2005), біохімічні дослідження крові. Ці методи використовувалися з метою розширення діагностичних можливостей при інших фрормах контролю. У кінці 2013 р. лікарями-кураторами з видів спорту було проведено аналіз усіх фрорм медичного контролю за фрункціональним станом зазначеного контингенту спортсменів, на підставі чого було заповнено звітні фрорми диспансеризації. В результаті було визначено основні тенденції зміни частоти і характеру перебігу соматичної патології в юних спортсменів протягом першого-третього етапів багаторічної спортивної підготовки та перспективних напрямків подальшого поглибленого вивчення проблеми впливу факторів тренувальної та змагальної діяльності на виникнення та перебіг соматичної патології у спортсменів дитячого та юнацького віку.

Обчислення отриманих результатів дослідження проводили на персональному комп'ютері із застосуванням стандартних пакетів програм для статистичної обробки даних наукових досліджень - Microsoft Excel 2000 і Statistica (версія 6.0). Для обробки статистичних даних 
ТАБЛИЦЯ 1 - Розподіл соматичної патології за нозологічними групами залежно від спортивної спеціалізації (за даними диспансеризації 2013 р. (n = 1181)

\begin{tabular}{|c|c|c|c|c|c|c|c|}
\hline \multirow[b]{2}{*}{ Група видів спорту } & \multirow{2}{*}{$\begin{array}{c}\text { Кількість } \\
\text { спорт- } \\
\text { сменів } 3 \\
\text { патологією }\end{array}$} & \multicolumn{5}{|c|}{ Соматична система } & \multirow[b]{2}{*}{$\begin{array}{l}\text { Пере- } \\
\text { втома }\end{array}$} \\
\hline & & $\begin{array}{l}\text { Серцево- } \\
\text { судинна }\end{array}$ & $\begin{array}{l}\text { Респі- } \\
\text { раторна }\end{array}$ & Травна & $\begin{array}{l}\text { Сечови- } \\
\text { відна }\end{array}$ & $\begin{array}{l}\text { Репро- } \\
\text { дуктив- } \\
\text { на }\end{array}$ & \\
\hline Ігрові & 327 & $\begin{array}{c}165 \\
(50,46) \\
\end{array}$ & $\begin{array}{c}52 \\
(15.90) \\
\end{array}$ & $\begin{array}{c}59 \\
(18,04) \\
\end{array}$ & $\begin{array}{c}31 \\
(10,40) \\
\end{array}$ & $\begin{array}{c}14 \\
(4,28) \\
\end{array}$ & $\begin{array}{c}6 \\
(0,31) \\
\end{array}$ \\
\hline Єдино-борства & 4329 & $\begin{array}{c}190 \\
(57,75) \\
\end{array}$ & $\begin{array}{c}65 \\
(19,76) \\
\end{array}$ & $\begin{array}{c}42 \\
(12,77) \\
\end{array}$ & $\begin{array}{c}12 \\
(3,65) \\
\end{array}$ & $\begin{array}{c}8 \\
(2,43) \\
\end{array}$ & $\begin{array}{c}2 \\
(0,6) \\
\end{array}$ \\
\hline Складно-координаційні & 193 & $\begin{array}{c}70 \\
(36,27)\end{array}$ & $\begin{array}{c}27 \\
(13,99)\end{array}$ & $\begin{array}{c}36 \\
(18,65)\end{array}$ & $\begin{array}{c}22 \\
(11,40)\end{array}$ & $\begin{array}{c}38 \\
(19,69)\end{array}$ & - \\
\hline $\begin{array}{l}\text { Комбіновані та багато- } \\
\text { борство }\end{array}$ & 88 & $\begin{array}{c}41 \\
(46,59)\end{array}$ & $\begin{array}{c}13 \\
(14,77) \\
\end{array}$ & $\begin{array}{c}10 \\
(11,36)\end{array}$ & $\begin{array}{c}17 \\
(19,32)\end{array}$ & $\begin{array}{c}7 \\
(7,95) \\
\end{array}$ & - \\
\hline Швидкісно-силові & 91 & $\begin{array}{c}20 \\
(21,98)\end{array}$ & $\begin{array}{c}19 \\
(20,88)\end{array}$ & $\begin{array}{c}12 \\
(13,19)\end{array}$ & $\begin{array}{c}15 \\
(16,48) \\
\end{array}$ & $\begin{array}{c}20 \\
(21,98) \\
\end{array}$ & $\begin{array}{c}5 \\
(5,49) \\
\end{array}$ \\
\hline Циклічні & 153 & $\begin{array}{c}62 \\
(40,52) \\
\end{array}$ & $\begin{array}{c}16 \\
(10,46) \\
\end{array}$ & $\begin{array}{c}16 \\
(10,46)\end{array}$ & $\begin{array}{c}28 \\
(18,30) \\
\end{array}$ & $\begin{array}{c}22 \\
(14,38) \\
\end{array}$ & $\begin{array}{c}9 \\
(5,88) \\
\end{array}$ \\
\hline Усього: & 1181 & 548 & 192 & 175 & 125 & 119 & 22 \\
\hline
\end{tabular}

Примітка. У дужках - \% загальної кількості спортсменів із соматичною патологією у кожній групі видів спорту.

застосовували класичні методи варіаційної статистики (розрахунок середніх величин, оцінка їх достовірності) [19]. Для оцінки достовірності відмінності середніх величин використовували критерій Стьюдента (для нерівних вибірок, нормального розподілу). Відмінності між показниками в різних групах обстежених спортсменів, котрі мали соматичну патологію, вважали статистично значущими при р < 0,05. Проведені розрахунки довели, що всі кількісні дані, отримані у результаті наших досліджень, мають нормальний розподіл за критеріями Колмогорова-Смирнова [19].

Результати дослідження та їх обговорення. У ході вивчення звітної документації встановлено, що загальна кількість спортсменів 3 патологією різних органів і систем становила 3200 (58,86 \%) осіб, при цьому найбільшу кількість відхилень було діагностовано у діяльності соматичних систем організму юних спортсменів; даних станів було зареєстровано у 1181 спортсмена $(36,91 \%$ загальної кількості спортсменів із патологією). Нами було також проведено розподіл структури соматичної патології різних нозологічних груп залежно від спортивної спеціалізації обстежених, з метою визначення видів спорту, зайняття якими призводять до більшої кількості патологічних відхилень у діяльності соматичних систем спортсменів (табл. 1). Але результати цього дослідження було раніше надано нами в інших наукових працях $[14,15]$, а більш поглиблене вивчення впливу факторів спортивної спеціалізації на функціональний стан спортсменів юного віку $€$ перспективним напрямком подальших наукових досліджень.
У межах досягнення мети даної статті нами було визначено особливості перебігу та стадії соматичних патологічних станів, діагностованих у юних спортсменів за диспансерними звітами лікарів кураторів видів спорту за 2013 р. (рис. 1 ).

Більшість зареєстрованих соматичних захворювань мали гострий перебіг і були діагностовані у 887 $(75,11 \%)$ спортсменів. У 294 (24,89\%) юних атлетів захворювання мали хронічний перебіг (стадія ремісії), при цьому у 46 спортсменів захворювання було виявлено при первинному огляді.

Загострення хронічних захворювань протягом року було зареєстровано у 106 (8,98\%) спортсменів; з них 68 (5,76 \%) після курсу лікування відновили тренувальну діяльність у повному обсязі, а 38 (3,22 \%) було відсторонено від тренувальної діяльності для лікування в умовах амбулаторії чи стаціонару і подальшої реабілітації, але після цього їх не було допущено до тренувальної діяльності.

Таким чином, нами встановлено, що 3/4 випадків патологічних змін у діяльності соматичних систем організму юних спортсменів мають гострий перебіг, а їх виникнення прямо або опосередковано обумовлено факторами тренувальної та змагальної діяльності обстежених: великі за обсягом та потужністю фрізичні навантаження, які не відповідають резервним можливостям

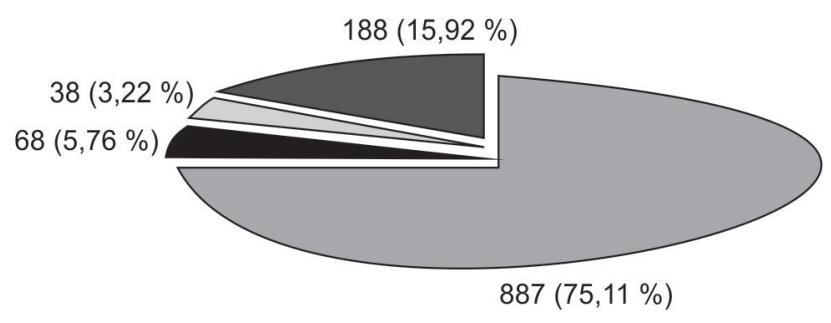

Гострий перебіг Загострення хронічної патології

Випадки відсторонення від тренувань Ремісія

Рисунок 1 - Характер перебігу соматичної патології, діагностованої в юних спортсменів (за даними диспансеризації 2013 р., $\mathrm{n}=1181$ ) 
ТАБЛИЦЯ 2 - Клінічний перебіг соматичної патології різних нозологічних груп у спортсменів, які тренуються на першому-третьому етапах багаторічної підготовки $(\mathrm{n}=1181)$

\begin{tabular}{|l|c|c|c|}
\hline \multirow{2}{*}{$\begin{array}{c}\text { Соматична } \\
\text { система }\end{array}$} & $\begin{array}{c}\text { Кількість } \\
\text { спортсме- } \\
\text { нів із пато- } \\
\text { логією }\end{array}$ & $\begin{array}{c}\text { Кількість спортсменів із різними } \\
\text { формами патології }\end{array}$ \\
\cline { 3 - 4 } & $\begin{array}{c}\text { хронічний } \\
\text { перебіг, абс./\% }\end{array}$ & $\begin{array}{c}\text { гострий перебіг, } \\
\text { абс./\% }\end{array}$ \\
\hline Серцево-судинна & 548 & $116(21,17)$ & $432(78,83)$ \\
\hline Сечовивідна & 125 & $7(5,60)$ & $118(94,40)$ \\
\hline Репродуктивна & 119 & $100(84,03)$ & $19(15,97)$ \\
\hline Травна & 175 & $49(28,00)$ & $126(72,00)$ \\
\hline Респіраторна & 192 & $22(11,45)$ & $170(88,54)$ \\
\hline Усього: & $\mathbf{1 1 8 1}$ & $\mathbf{2 9 4}(\mathbf{2 4 , 8 9 )}$ & $\mathbf{8 8 7}(\mathbf{7 5 , 1 1 )}$ \\
\hline
\end{tabular}

організму спортсменів; недотримання вікових норм при селекційному відборі дітей до занять спортом та при складанні тренувальних програм; форсований перехід до змагальної діяльності; дуже щільний графрік змагальних стартів; недотримання термінів допуску до тренувальної діяльності після перенесених захворювань і травм, а також більшість фракторів спортивної спеціалізації (що було підтверджено даними аналізу амбулаторних карток спортсменів). Зареєстровані гострі стани піддаються корекції і за умов своєчасної діагностики, лікування, реабілітації не перейдуть у хронічну стадію, тобто не загрожуватимуть процесу підготовки спортсменів. Вищезазначені фрактори тренувальної та змагальної діяльності призвели до загострення практично половини хронічних соматичних захворювань, причому у $1 / 3$ дітей-спортсменів дані стани, у силу тяжкості процесу, вимагали тривалого відсторонення від тренувальної діяльності, більш повного обстеження і лікування у медичних установах за профілем патології.

Для визначення ступеня впливу фізичних та психоемоційних навантажень тренувального процесу на функціональний стан соматичних систем організму юних спортсменів слід розглядати структуру діагностованої патології згідно 3 характером клінічного перебігу $[18,24]$ (табл. 2). При аналізі патології серцево-судинної системи (ССС) нами окремо розглядалися показники частоти виникнення станів фізичного перенапруження, перетренування - найнесприятливіших клінічних проявів дисфункціональних порушень ССС у спортсменів [25].

Отримані дані свідчать про те, що клінічний перебіг діагностованих у спортсменів захворювань був різним для всіх соматичних систем. Це пов'язано з тим, що соматичні системи неоднаковою мірою адаптуються до фрізичних навантажень, тобто мають різну фрункціональну потужність структурних утворень. При тривалому компенсаторному напруженні деякі фрункції можуть виснажуватися i тоді фрункціонування організму відбувається на передпатологічному або патологічному рівнях. Такий стан дизадаптації призводить до розвитку перевтоми, перенапруження, значного зниження працездатності, а надалі - до виникнення захворювань $[1,23]$. Проблема ускладнюється тим, що до спорту приходять діти, які вже мають приховану патологію, котра здатна маніфрестувати під час виконання значних за обсягом та інтенсивністю фрізичних навантажень [2, 22].

Серцево-судинна система $€$ однією 3 провідних у забезпеченні високої працездатності у спортсменів. Наявність дисфункціональних порушень у ССС значною мірою лімітує процес підготовки спортсменів [17]. За даними спеціалістів, до ранніх ознак дизадаптації серцево-судинної системи відносяться транзиторна гіпертензія, поява порушень на електрокардіограмі у стані спокою [21]. При аналізі ЕКГ у спортсменів найчастіше виявляється порушення процесів реполяризації, різко виражена синусова аритмія, міграція водія ритму, екстрасистолія, синоатриальні і атріовентрикулярні блокади [10]. Найчастіше зрив адаптації ССС проявляється розвитком міокардіодистрофіії різного ступеня тяжкості, яка $€$ крайнім проявом дисфункції у спортсменів, клінічно маніфестує в гострій і хронічній фрормах, що виникають внаслідок гострого та хронічного фрізичного перенапруження. На думку авторів, дані стани реєструються у 4-11 \% спортсменів різних спеціалізацій [25].

У нашому дослідженні патологію ССС було зареєстровано у 548 (46,40 \% загальної кількості соматичних захворювань) спортсменів. 3 них $116(21,16 \%)$ мали захворювання хронічного характеру і перебували на диспансерному обліку у лікаря-кардіолога. Дані стани переважно представлені диспластичною кардіопатією (ДКП): пролапсом клапанів та аномально розташованими хордами. У найбільшій кількості ДКП було діагностовано у представників спортивних ігор та складнокоординаційних видів спорту, що імовірно обумовлено специфрікою відбору у ці види спорту відповідно до антропометричних даних (акселерати та ретарданти). Слід звернути увагу на те, що у спортсменів зазначених спеціалізацій, які тренувалися у групах початкової підготовки, наявність хронічних станів не обмежувала тренувальну діяльність у повному обсязі, у той час як у спортсменів груп початкової базової підготовки дані стани мали тенденцію до загострення у одному випадку з десяти, а у групах 
спеціалізованої базової підготовки - у одному випадку з шести. Тобто кількість загострень хронічних станів ССС збільшилась практично у два рази. У 78,83 \% випадків дисфрункції ССС мали гострий перебіг і виражалися розладами ритму серця (аритмія, тахікардія, брадикардія, поодинокі екстрасистоли, міграція водія ритму). Найчастіше гострі відхилення у діяльності ССС реєструвалися у представників спортивних ігор, циклічних видів та єдиноборств, які тренувалися на етапах початкової та спеціалізованої базової підготовки та мали щільний графік тренувальних зборів і змагань. Причини виникнення зареєстрованих змін пов'язані з віковими особливостями системи кровообігу, її тісним зв'язком з темпами росту і дозрівання організму дітей-спортсменів та перебудовою діяльності ендокринної та нервової систем. У даному випадку надмірні, часом форсовані, фрізичні навантаження, що перевищують адаптаційні можливості ССС юних спортсменів, призвели до виникнення вищевказаних функціональних відхилень.

Стани фрізичного перенапруження ССС нами було діагностовано у $1,86 \%$ юних спортсменів високої спортивної кваліфікації, які тренувалися на етапі спеціалізованої базової підготовки. Клінічно ці стани були представлені: симптомами фрізичної перевтоми - 5 спортсменів (частіше представники швидкісно-силових видів та єдиноборств); перенапруження ССC -8 осіб (частіше представники циклічних видів); дистрофії міокарда фрізичного перенапруження - 3 спортсмени (циклічні види); перетренованістю - 6 спортсменів (частіше представники ігрових та швидкісно-силових видів). Отже, високі вимоги, що пред'являються сучасним процесом підготовки юних спортсменів до серцево-судинної системи, сукупно з процесами росту, призводять до виникнення функціональних змін. Дані стани, за відсутності коригуючих заходів, можуть у подальшому спровокувати виникнення структурних змін у функціональних утвореннях ССС і розвиток захворювань.

Таким чином, нами встановлено тенденцію до збільшення кількості патологічних відхилень фуннкціонального стану ССС у дітей-спортсменів протягом першого-третього етапів багаторічної підготовки. Це визначило перспективи необхідності поглибленого вивчення сукупності екзогенних та ендогенних фракторів ризику виникнення гострих та загострення хронічних станів даної системи для подальшого вдосконалення системи профілактичних і реабілітаційних заходів та інтеграції їх у практичну діяльність.

Важливу роль у забезпеченні високої працездатності відіграє стан респіраторної системи.
У цьому зв'язку слід зазначити тісний фрізіологічний взаємозв'язок органів дихання і ССС. У спортивній фрізіології механізми адаптації органів двох морфологічних систем розглядають у нерозривній функціональній єдності, розглядаючи іï як кардіореспіраторну. Невідповідність фуункціонального стану органів системи дихання рівню фрізичних навантажень, що пропонує процес підготовки спортсмена, призводить до виникнення гіпервентиляції, при якій можливе пошкодження слизової оболонки дихальних шляхів із подальшим розвитком обструкції [6]. Даний фракт слід ураховувати при складанні реабілітаційних програм для спортсменів зимових видів спорту та атлетів, що тренуються на "свіжому повітрі» [19]. У клінічній практиці спортивної медицини найчастіше реєструються такі захворювання бронхолегеневої системи, як бронхіт, пневмонія, бронхіальна астма [12].

У нашому дослідженні захворювання респіраторної системи протягом року було діагностовано у 192 юних спортсменів (16,26 \% загальної кількості соматичних захворювань). Найбільше випадків зареєстрованих нами захворювань $(88,54 \%)$ мали гострий перебіг (ларингіт, трахеобронхіт). Зазначені стани було діагностовано переважно у представників циклічних та ігрових видів спорту. Їхнє виникнення реєструвалося в осінньо-весняний період, який для більшості видів спорту збігається 3 періодом максимальних фрізичних навантажень. Хронічний перебіг мали $11,46 \%$ захворювань респіраторної системи, 3 них 7,64 \% випадків клінічно проявлялися загостреннями трахеїтів і бронхітів, виникнення яких зареєстровано у спортсменів, котрі тренуються на другому-третьому етапах багаторічної підготовки; 3,82 \% випадків склали загострення хронічних захворювань респіраторної системи, при цьому найбільший відсоток припадав на частку бронхіту 3 обструктивним компонентом, який реєструвався у спортсменів молодшої вікової групи, які тренувалися на етапі початкової підготовки. У половині випадків причиною обструкції була алергія (сезонні полінози у період квітіння).

Таким чином, проведені дослідження підтвердили дані наукової літератури про те, що кількість захворювань респіраторної системи у спортсменів збільшується відповідно зростанню рівня спортивної майстерності, а їхнє виникнення тісно пов'язане з кліматичними фракторами, у той час як тренувальні навантаження виступають лише у ролі тригера $[6,12,19]$.

У процесі адаптації спортсмена до фрізичних навантажень і підтримки високої фрізичної працездатності дуже важливу роль відіграють органи 
шлунково-кишкового тракту. Відповідно до класичних уявлень про розвиток генералізованого адаптаційного синдрому автора теорії про стрес Г. Сельє, саме функціональні зміни на рівні шлунково-кишкового тракту слід розглядати як один із показників рівня впливу стрес-орактора на організм [24]. Це підтверджується різноманітністю клінічних прояв та варіабельністю чисельності захворювань і дисфункцій шлунково-кишкового тракту в спортсменів протягом циклу річної підготовки. Епідеміологічні дослідження останніх років свідчать про те, що частота даної патології у спортсменів неухильно зростає [3, 5], однак наявні у спеціальній літературі статистичні дані нечисленні та суперечливі.

Патологічні розлади у діяльності шлунковокишкового тракту протягом року нами було зареєстровано у 175 спортсменів (14,82 \% кількості соматичних захворювань). У 72 \% випадків дані стани виявлялися у гострій фрормі, та проявлялися клінічно у вигляді синдромів перенапруження шлунково-кишкового тракту (диспепсичного - у спортсменів, котрі тренуються на етапі початкової підготовки, та печінкового больового - у спортсменів, які займаються на етапах попередньої та спеціалізованої базової підготовки), що свідчить про їх фрункціональне походження та $\epsilon$ наслідком дисбалансу між фракторами тренувального процесу і функціональними резервами організму дітей-спортсменів. На етапі спеціалізованої базової підготовки виникнення печінкового больового синдрому у спортсменів було обумовлено розтягуванням капсули печінки (геодинамічний генез - частіше у представників циклічних й ігрових видів) та гіперкінезом жовчовивідних проток (холестатичний генез - у представників складнокоординаційних видів) [24]. 3 проведеного аналізу впливає, що у юних спортсменів високих спортивних розрядів, які мають стаж тренувальної діяльності більше п'яти років, у 7 \% випадків, незважаючи на збалансований харчовий раціон, реєструвалися загострення хронічних захворювань (дискінезіі жовчовивідних шляхів, гіперацидні гастрити). Виникнення даних станів обумовлено фракторами спортивної спеціалізації: біомеханічними особливостями тренувальної та змагальної діяльності (складнокоординаційні, циклічні види спорту), нераціональним прийомом фрармакологічних препаратів (швидкісно-силові, циклічні види), відсутністю належного рівня відновлювальних заходів, що підкреслює багатопрофрільність проблеми превентивної реабілітації функціональних порушень системи травлення у спортсменів, що виникають у результаті тренувальної діяльності.
У процесі адаптації спортсменів до фрізичних навантажень важливу роль відіграє повноцінне фрункціонування сечовивідної системи як такої, що утилізує кінцеві продукти метаболізму м'язової діяльності і значною мірою забезпечує сталість водно-сольового балансу в організмі під час виконання тренувальних навантажень [26]. Аналіз статистичних даних важливий як для оцінки частоти виникнення і прогнозування уронефрологічних захворювань у спортсменів, так і для визначення ефективності лікувальної роботи та розробки стратегії профрілактичних заходів. Однак нам практично не вдалося знайти у науковій літературі статистичних даних про виявлення уронефрологічної патології у спортсменів.

У проведеному дослідженні захворювання сечовивідної системи було діагностовано у 125 спортсменів дитячого та підліткового віку (10\% загальної кількості соматичних захворювань). У 118 (94,40 \%) спортсменів захворювання мали гострий перебіг, з них: 64,20 \% випадків мали запальну етіологію (частіше - уретрит, цистит, рідше - пієлонефрит), реєструвалися в холодну пору року переважно у спортсменів ігрових та циклічних видів спорту і були пов'язані швидше 3 порушенням заходів самопрофрілактики, ніж з високими тренувальними навантаженнями; 30,20 \% захворювань проявлялися у вигляді сечосольового діатезу. Ці патологічні відхилення реєструвалися в юних спортсменів високої кваліфрікації, які тренувалися на етапі спеціалізованої базової підготовки. Виникнення даних дисоункцій було спровоковано негативними біохімічними зміщеннями рідких середовищ організму за відсутності належного рівня відновлювальних заходів і раціонального поєднання відпочинку з фізичними навантаженнями під час передзмагального та змагального періодів у циклі річної підготовки, що свідчило про невідповідність запропонованих тренувальних програм рівню функціональних можливостей юних спортсменів, котрі мають високу спортивну кваліфікацію.

Проблема розвитку захворювань репродуктивної системи у спортсменок на сучасному етапі розвитку спорту для профрілактики серйозних порушень у здоров'ї жінки є актуальною і достатньо вивченою [11, 13]. Представлені фрактичні дані свідчать про прямий зв'язок між фракторами тренувальної діяльності та виникненням дисорункцій даної системи. Цифрові показники захворюваності органів репродуктивної системи спортсменок у різних авторів практично не мають відмінностей. Автори зійшлися на думці, що протягом перших двох років тренування у половини спортсменок спостерігається затримка фрормування 
вторинних статевих ознак. У спортсменок, які займаються традиційно чоловічими видами спорту, виявляється відставання темпів статевого дозрівання на 2-3 роки, а через 3-4 роки регулярних занять спортом у всіх спортсменок визначається загальна спрямованість до ретардації розвитку вторинних статевих ознак. Найбільш поширеними клінічними проявами дисфункцій репродуктивної системи є: яскраво виражений передменструальний синдром, розлади менструального циклу. Останні проявляються у вигляді: альгоменореї (мізерні менархе), опсоменореї (подовження циклу між початком менархе більше 40 днів), аменореї (стійкої відсутності менархе протягом декількох місяців).

У проведеному досліджені захворювання репродуктивної системи нами було діагностовано у 119 спортсменок (10,08 \% загальної кількості соматичних захворювань). Патологічні розлади жіночої статевої сорери реєструвалися частіше у представниць складнокоординаційних, циклічних і швидкісно-силових видів спорту, які тренувалися на другому-третьому етапах підготовки. Дані стани проявлялися у вигляді розладів менструального циклу (аменорея, олігоменорея, опсоменорея) і затримки статевого розвитку, мали функціональний характер і були опосередковані тренувальними і змагальними навантаженнями, порушенням режиму харчування («скидання ваги», виснажливі дієти). Зі 100 випадків захворювань 70 виявлені уперше, але, з урахуванням патогенезу та клінічної картини, у гінекологічній практиці дані стани належать до патології хронічного перебігу. У 2,43 \% дівчаток реєструвалися запальні захворювання органів малого тазу, які виникали в холодну пору року, і в 0,97 \% вагінози вірусного та бактеріального генезу, які не мали явного причинного зв'язку із заняттями спортом.

Таким чином, фрактори тренувальної діяльності в сукупності з процесами росту організму призводять до розвитку соматичних захворювань спортсменів переважно гострого перебігу, що свідчить на користь їхнього функціонального походження $[6,8,12]$.

Спортсмени з соматичними захворюваннями хронічного перебігу перебувають під диспансерним наглядом лікарів-фрахівців за профрілем патології, отримують корекційне лікування та продовжують тренувальний процес. Особливо цікавою у дослідницькому плані $€$ інорормація про кількість спортсменів у диспансерній групі та особливості перебігу діагностованих у них хронічних соматичних захворювань протягом декількох років. Отримані дані дозволяють робити висновок

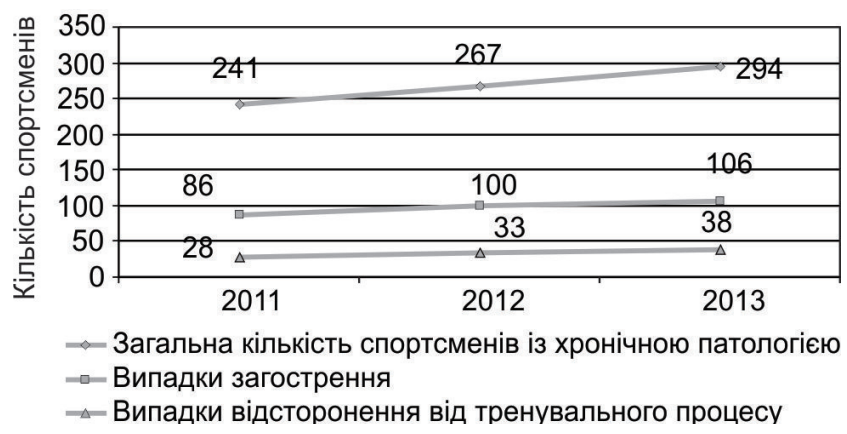

Рисунок 2 - Зміни кількості спортсменів із хронічними соматичними захворюваннями у диспансерній групі за період з 2011 по 2013 р.

про ступінь впливу тренувальних і змагальних навантажень на перебіг хронічної соматичної патології, яка не $\epsilon$ абсолютним протипоказанням до занять спортом, тобто за умови правильної побудови процесу підготовки спортсменів, з дотриманням принципів індивідуалізації, не буде лімітувати зростання рівня спортивної майстерності [2]. Нами було проведено аналіз динаміки зміни показників кількості спортсменів із хронічною соматичною патологією та її стадій за трирічний період часу (рис. 2)

Дані проведеного дослідження дозволили констатувати, що протягом трирічного періоду кількість спортсменів із хронічною патологією у диспансерній групі збільшилася на 18,03 \%, показник частоти загострень хронічних захворювань - на 18,87\%, а кількість спортсменів із загостреннями хронічних захворювань, ступінь тяжкості яких не дозволяє продовжити заняття спортом, - на 26,32\%.

Таким чином, отримана негативна динаміка зміни показників захворюваності хронічного перебігу свідчить про нагальну необхідність розробки програм реабілітаційної та превентивної спрямованості, реалізація яких дозволить скоротити кількість випадків виникнення та загострення хронічних захворювань у юних спортсменів.

\section{Висновки}

Аналіз звітної документації щодо диспансеризації спортсменів різних спеціалізацій у віці 8-17 років дозволив встановити ряд особливостей частоти виникнення та клінічного перебігу соматичної патології у спортсменів різних спеціалізацій у процесі спортивного становлення, які потребують більш поглибленого та ретельного вивчення.

1. Фактори тренувальної діяльності, до яких відносять: спортивну спеціалізацію, етап спортивної підготовки, період у циклі річної підготовки, а також педагогічні недоліки при проведенні процесу тренування (фрізичні навантаження, що 
перевищують фрункціональні можливості організму, перенесення до практики дитячо-юнацького спорту методик тренування дорослих спортсменів, застосування у тренувальній діяльності складних технічних елементів тощо) в сукупності з процесами росту організму призводять до виникнення дисорункціональних розладів у діяльності соматичних систем організму юних спортсменів.

2. Безумовно, значна кількість соматичних захворювань має гострий перебіг (у нашому дослідженні - 75,11 \% загальної кількості спортсменів із соматичною патологією), тобто фуннціональні відхилення носять зворотний характер та при своєчасних діагностиці, профрілактиці, лікуванні та подальшій реабілітації не перейдуть у хронічну фрорму та не будуть загрожувати процесу підготовки юних спортсменів. Водночас хронічні соматичні захворювання реєструються значно рідше (у нашому випадку - 24,89 \%), а їхня наявність у процесі зростання спортивної майстерності значно впливає на функціональний стан спортсменів, призводить до загострень патологічних станів $(8,98$ \% загальної кількості соматичної патології), тим самим лімітує зростання рівня спортивної майстерності. Це підтверджено даними спостереження за групою спортсменів із патологією, які знаходяться під диспансерним наглядом з приводу захворювань. Дані положення, безумовно, потребують більш ретельного вивчення в аспектах впливу екзогенних та ендогенних фракторів на зростання кількості показників соматичної патології у юних спортсменів та показників переходу іï гострих фрорм у хронічні, що дозволило визначити перспективи подальших досліджень.

3. У спортсменів, які тренуються у групах початкової підготовки, у більшості випадків діагностується соматична патологія гострого перебігу

\section{Література}

1. ГаßрилоВа E. А. Современные представления о синдроме перетренированности / Е. А. Гаврилова // Спорт. медицина: наука и практика. - 2013. - № 1 (10). - С. 77-78.

2. Гладков В. Н. Некоторые особенности заболеваний, травм, перенапряжений и их профилактика в спорте высших достижений / В. Н. Гладков. - М.: Сов. спорт, 2007. $386 \mathrm{c}$.

3. Грязных А. В. Восстановление секреторной активности пищеварительных желез в условиях напряженной мышечной работы / А. В. Грязных // Физиология человека. - 2012. - Т. 38, № 1. - С. 110-118.

4. Деревоедов В. В. Профессиональные заболевания в спорте высших достижений / В.В.Деревоедов // ЛФК и массаж, спорт. медицина. - 2008. - № 8 (56). C. $3-6$.
(78,47 \% загальної кількості спортсменів у даній групі). Патологія хронічного перебігу (21,53%) у більшості випадків має спадкову або пренатальну етіологію, її виникнення не пов'язано із заняттями спортом. Водночас у спортсменів, котрі тренуються на третьому етапі (спеціалізованої базової підготовки), гострі стани $(73,01 \%)$ набувають чіткого характеру дисфункцій, опосередкованих фракторами тренувальної та змагальної діяльності, що підтверджується даними диспансерного спостереження за спортсменами старшої вікової групи. На цьому етапі спортивної підготовки також зареєстровано збільшення кількості соматичної патології хронічного перебігу до 26,99 \% за рахунок зростання кількості випадків переходу гострих станів у хронічну форму, що, безумовно, має причинний зв'язок із зайняттями спортом та потребує ретельного поглибленого вивчення у аспектах балансу між фракторами процесу підготовки, функціональним станом спортсмена та його резервними можливостями.

Перспективи подальших досліджень. Зазначені особливості структури та клінічного перебігу соматичних захворювань у юних спортсменів дозволили визначити основні тенденції збільшення частоти та зміни клінічного перебігу соматичної патології, обґрунтувати доцільність поглибленого вивчення проблеми впливу сукупності фракторів на функціональний стан зазначеного контингенту для розробки програм фрізичної реабілітації превентивної спрямованості, інтеграції їх у процес підготовки спортсменів, починаючи з його початкових етапів, з метою зниження показників первинної захворюваності, а також необхідність побудови програм фрізичної реабілітації спортсменів після соматичних захворювань, реалізація яких буде перешкоджати хронізації гострих патологічних станів.

\section{References}

1. Gavrilova E. A. Modern notions about overtraining syndrome / E. A. Gavrilova // Sport. meditsina: nauka i praktika. - 2013. - N 1 (10). - P. 77-78.

2. Gladkov V. N. Some peculiarities of diseases, traumas, overexertions and their prevention in elite sport / V. N. Gladkov. - Moscow: Sov. sport, 2007. - 386 p.

3. Griaznykh A. V. Recovery of digestive gland secretion during strenuous muscular work / A. V. Griaznykh // Fiziologiya cheloveka. - 2012. - Vol. 38, N 1. - P. 110118.

4. Derevoyedov V. V. Professional diseases in elite sport / V. V. Derevoyedov // LFK i massazh, sportivnaya meditsina. - 2008. - N 8 (56). - P. 3-6.

5. Dolgova T. I. Diagnostics and rehabilitative treatment of chronic gastritis, associated with Helicobacter pylori 
5. ДолгоВа Т. И. Діагностика и восстановительное лечение хронического гастрита, ассоциированного Helicobacter pylori у спортсменов / Т. И. Долгова, В. П. Мудров // Физкультура в профиилактике, лечении и реабилитации. 2007. - № 2 (21). - С. 14-18.

6. ЗайкоВ С. В. Бронхиальная астма и спорт / С. В. Зайков // Клініч. імунологія. Алергологія. Інфектологія. 2011. - № 3 спец. вып. - С. 24-32.

7. Казимирко Н. К. Предпатологические и патологические изменения ЛОР-органов при нерациональных занятиях спортом / Н. К. Казимирко, Е. Р. Линниченко, В. В. Флегонтова, И. В. Деменков // Заг. патологія та патолог. фрізіологія. - 2010. - Т. 5, № 3 дод. - С. 99-107.

8. Казимирко Н. К. Метаболическая кардиомиопатия как проявление хронического перенапряжения у спортсменов / Н. К. Казимирко, Н. К. Флегонтова, Е. Р. Линниченко // Заг. патологія та патолог. фрізіологія. - 2011. T. 6, № 2. - С. 27-41.

9. Кашуба В. А. Технологии, сберегающие и корригирующие здоровье, в системе подготовки юных спортсменов / В. А. Кашуба, П. А. Яковенко, Т. А. Хабинец // Спорт. медицина. - 2008. - № 2. - С. 140-147.

10. КомолятоВа В. Н. Электрокардиографические особенности у юных элитных спортсменов / В. Н. Комолятова, Л. М. Макаров, В. О.Колосов // Педиатрия. - 2013. Т. 92, № 3. - С. 136-140.

11. КулиеВ Э. Р. Влияние различных тренировочных факторов на менструальную функцию спортсменок / Э. Р. Кулиев // Здоровье женщины. - 2011. - № 4. - С. 157-158.

12. Лінніченко О. Р. Передпатологічні і патологічні зміни бронхолегеневої системи як наслідок нераціональних занять спортом / О. Р. Лінніченко // Заг. патологія та фрізіологія. - 2012. - Т. 7, № 1. - С. 6-12.

13. ЛimiceЉич Л. В. Репродуктивне здоров'я спортсменок високої кваліфікації: авторефр. дис. ... канд. мед. наук: спец. 14.01.24 / Л. В. Літісевич; Нац. ун-т фріз. виховання і спорту України. - Д., 2012. - 24 с.

14. Люгайло С. С. Структура соматической патологии, диагностированной у юных спортсменов - обоснование концепции физической реабилитации в процессе подготовки / С. С. Люгайло / / Теорія і практика фріз. виховання. 2014. - № 1. - С. 168-175.

15. Люгайло С. С. Заболеваемость спортсменов в аспектах специализации /С. С. Люгайло, Н.К.Криволап // Спорт. медицина, лік. фрізкультура та валеологія - 2014: матеріали Х Міжнар. наук.-практ. конф. - Одеса, 29-30 трав. 2014 р. - Одеса: Вид-во ОДМУ, 2014. - С. 135-138.

16. Марудно А. С. Дисплазия соединительной ткани у спортсменов / Ю. И. Марухно, А. С. Пянтковский // Мед. перспективи. - 2012. - Т. 17, № 1. - С. 114-118.

17. Орджоникидзе 3. Г. Выраженная синусовая брадикардия у спорстменов-подростков: норма или патология / З. Г. Орджоникидзе, В. И. Павлов, Е.М.Цветкова // Педиатрия. - 2009. - № 3. - С. 35-39.

18. Орловская Ю. В. Теоретико-методологическое обоснование профилактическо-реабилитационного направления в системе подготовки спортивного резерва (на примере специализации баскетбол): автореф. дис ... док-ра пед. наук: спец. 13.00.04. - Малаховка, 2000. - 22 с.

19. Реброва О. Ю. Статистический анализ медицинских данных. Применение пакета прикладных программ Statistika 6.0 / О. Ю. Реброва. - М.: МедиаСфера, 2006. - 312 с.

20. СаВельева М. И. Физические нагрузки, спорт и гиперактивность бронхов / М. И. Савельева, А. Н. Цой // Consilium Medicum. - 2009. - № 3. - C. 37-44. in athletes / T. I. Dolgova, V. P. Mudrov // Fizkultura v profilaktike, lechenii i reabilitatsii. - 2007. - N 2 (21). P. $14-18$

6. Zaykov S. V. Bronchial asthma and sport / S. V. Zaykov// Klinich. imunologiia. Alerholohiia. Infektolohiia. 2011. - N 3 spec. iss. - P. 24-32.

7. Kazimirko N. K. Pre-pathological and pathological changes of ENT organs during irrational sports sessions / N. K. Kazimirko, E. R. Linnichenko, V. V. Flehontova, I. V. Demenkov // Zah. patolohiia ta patoloh. fiziolohiia. - 2010. Vol. 5, N 3 suppl. - P. 99-107.

8. Kazimirko N. K. Metabolic cardiomyopathy as a manifestation of chronic overexertion in athletes / N. K. Kazimirko, N. K. Flehontova, E. R. Linnichenko // Zah. patolohiia ta patoloh. fiziolohiia. - 2011. - Vol. 6, N 2. - P. 27-41.

9. Kashuba V. A. Technologies, preserving and correcting health, in the system of young athlete preparation / V. A. Kashuba, P. A. Yakovenko, T. A. Khabinets // Sport. meditsina. - 2008. - N 2. - P. 140-147.

10. Komoliatova V. N. Electrocardiographic peculiarities in young elite athletes / V. N. Komoliatova, L. M. Makarov, V. O Koloskov // Pediatriia. - 2013. - Vol. 92, N 3. P. $136-140$.

11. Kuliyev $E$. R. Impact of different training factors upon menstrual function of athletes / E. R. Kuliyev // Zdorovie zhenschiny. - 2011. - N 4. - P. 157-158.

12. Linnichenko O. R. Pre-pathologic and pathologic changes of bronchopulmonary system as a result of irrational sports sessions / O. R. Linnichenko // Zah. Patolohiia ta fiziolohiia. - 2012. - Vol. 7, N 1. - P. 6-12.

13. Litisevych $L$. V. Reproductive health of highly skilled female athletes: author's abstract for Ph.D. in Medicine: speciality 14.01.24 / L. V. Litisevych; National University of Physical Education and Sport of Ukraine. - Dnipropetrovsk, 2012. 24 p.

14. Liugailo S. S. Structure of somatic pathology detected in young athletes - substantiation of physical rehabilitation concept in the process of preparation / S. S. Liugailo // Teoriia i praktyka fiz. vykhovannia. - 2014. - N 1. - P. 168175.

15. Liugailo $S$. $S$. Incidence of diseases in athletes in specialization aspects /S. S. Liugailo, N. K. Kryvolap // Sport medicine, physical therapy and valeology - 2014: proceedings of the $X$ Intern. sci.-pract. conf. - Odesa, 2930 May 2014 p. - Odesa: OSMU Publishing House, 2014. P. $135-138$.

16. Marudno A. C. Dysplasia of connective tissue in athletes / Y. I. Marukhno, A. S. Piantkovsky / / Med. perspektyvy. - 2012. - Vol. 17, N 1. - P. 114-118.

17. Ordzhonikidze Z. G. Expressed sinus bradycardia in adolescent athletes: norm or pathology / Z. G. Ordzhonikidze, V. I. Pavlov, E. M. Tsvetkova // Pediatriya. - 2009. - N 3. P. $35-39$.

18. Orlovskaya $Y$. V. Theoretico-methodological substantiation of preventive and rehabilitative direction in the system of sports reserve preparation (based on basketball): author's abstract for Doctoral degree in Pedagogics: speciality 13.00.04. - Malakhovka, 2000. $22 \mathrm{p}$.

19. Rebrova O. Y. Statistical analysis of medical data. Application of Statistika 6.0 package / O. Y. Rebrova. Moscow: MediaSfera, 2006. -312 p.

20. Savelyeva M. I. Physical loads, sport and hyperactivity of bronchi / M. I. Savelyeva, A. N. Tsoy // Consilium Medicum. - 2009. - N 3. - P. 37-44. 
21. Скуратова H. A. Характеристика показателей сердечно-сосудистой системы у детей-спортсменов / Н. А. Скуратова // Кардиология в Беларуси. - 2012. № 2. - С. 58-67.

22. Сокрут B. Н. Медицинская реабилитация в спорте: рук. для врачей и студентов; под общ. ред. В. Н. Сокрута и В. Н. Казакова. - Донецк: Каштан, 2011. - 620 с.

23. Стеценко $E$. A. Эндогенная интоксикация как проявление дезадаптации у высококвалифицированных спортсменов / Е. А. Стеценко // Физиотерапия, бальнеология и реабилитация. - 2001. - № 6. - С. 43-46.

24. Тертышная E. C. Комплексная коррекция функциональных изменений гепатобилиарной системы у юных спортсменов / Е. С. Тертышная, И. Т. Корнеева, С. Д. Поляков, С. В. Ходарев // Физкультура в профилактике, лечении и реабилитации. - 2008. - № 3. - С. 19-24.

25. Флегонтова B. В. Ураження серця при гострому хронічному фізичному перенапруженні / В. В. Флегонтова, В. В. Макарець, О. А. Дичко [та ін.] // Аритмологія. 2012. - № 4. - С. 36-43.

26. Ширшов В. В. Структура урологических заболеваний у спортсменов / В. В. Ширшов В. Н. Шартанова, Д. Н. Дорончук и др.// Урология. - 2013. - № 4. - С. 24-26.

e-mail: ramoshkaite@bk.ru
21. Skuratova N. A. Characteristics of cardiovascular system indices in children-athletes / N. A. Skuratova / / Kardiologiya v Belarusi. - 2012. - N 2. - P. 58-67.

22. Sokrut V. N. Medical rehabilitation in sport: guide for physicians and students; edited by V. N. Sokrut and V. N. Kazakov. - Donetsk: Kashtan, 2011. $620 \mathrm{p}$.

23. Stetsenko $E$. A. Endogenic intoxication as deadaptation manifestation in highly skilled athletes / E. A. Stetsenko // Fizioterapiya, balneologiya i reabilitatsiya. - 2001. - N 6. P. 43-46.

24. Tertyshnaya E. S. Complex correction of functional changes of hepatobiliary system of young athletes / E. S. Tertyshnaya, I. T. Korneyeva, S. D. Poliakov, S. V. Khodarev // Fizkultura v profilaktike, lecheniyi i reabilitatsiyi. 2008. - N 3. - P. 19-24.

25. Flehontova V.V. Heart damages during acute and chronic physical overexertion / V. V. Flehontova, V. V. Makarets, O. A. Dychko [et al.] // Arytmolohiia. - 2012. - N 4. P. 36-43.

26. Shirshov V. V. Structure of urological diseases in athletes / V. V. Shirshov V. N. Shartanova, D. N. Doronchuk et al.// Urologiya. - 2013. - N 4. - P. 24-26.

Надійшла 08.09.2014 